\title{
Mandibular angle fracture due impacted third molar inclusion: case report
}

\author{
Fratura de ângulo mandibular devido a terceiro molar impactado: relato de caso
}

Fractura del ángulo mandibular debido tercer molar: reporte de un caso

\author{
Ellen Cristina GAETTI-JARDIM ${ }^{\mathbf{1}}$ \\ Cassiano Costa SILVA PEREIRA ${ }^{2}$ \\ Idelmo Rangel GARCIA JUNIOR ${ }^{3}$ \\ Elerson GAETTI-JARDIM JUNIOR ${ }^{4}$ \\ Julio Cesar Leite da SILVA ${ }^{5}$ \\ ${ }^{I}$ Adjunct Professor of Oral and Maxillofacial Surgery, of the Federal University of Mato Grosso do Sul, UFMS, Campo Grande-MS, Brazil \\ ${ }^{2}$ Doctor in Oral and Maxillofacial Surgery, Araçatuba Dental School, UNESP-Univ Estadual Paulista, Araçatuba - SP, Brazil \\ ${ }^{3}$ Adjunct Professor of Oral and Maxillofacial Surgery, Surgery and Integrated Clinic Department of Araçatuba Dental School, \\ UNESP-Univ Estadual Paulista, Araçatuba-SP, Brazil \\ ${ }^{4}$ Titular Professor of Microbiology, Pathology and Propaedeutical Clinical Department of Araçatuba Dental School \\ UNESP-Univ Estadual Paulista, Araçatuba - SP, Brazil \\ ${ }^{5}$ Associate Professor of Oral and Maxillofacial Surgery, of the Federal University of Mato Grosso do Sul, UFMS, Campo Grande-MS, Brazil
}

\begin{abstract}
Mandibular angle region is enshrined in literature as a fragile area because of the third molar presence further when its impaction shaping up as a rare complication associated with more attempts to extraction of the tooth. Several factors influence the possibility of fracture as gender, age, degree of dental inclusion and presence of associated injuries. The best form of treatment depending on the case is surgical, consisting of placing the intraosseous fixing devices. The purpose of facilitated and a conservative approach for the treatment of fractures of mandibular angle is displayed. Also, demystify the contraindication of intraoral access for cases of unfavorable fractures to displacement. This study, in addition, been reports two clinical cases of mandibular angle fractures in the presence of a third included molar treated by means of intraoral access set by Champy technique of external oblique line with the use of single board in office dental. Results: This approach is well suited to cases with little displacement of the fracture line and when the patient shows collaborator. This technique as well as fast, reduces spending on hospital besides reducing postoperative sequelae because it prevents the need for extra-oral access. Descriptors: Fracture Fixation; Therapeutics; Anesthesia, Local; Molar, Third.
\end{abstract}

\section{Resumo}

A região do ângulo mandibular está consagrada na literatura como uma área de baixa resistência à fratura, especialmente quando associada à remoção cirúrgica de terceiro molar impactado. Vários fatores influenciam a possibilidade de fratura, como sexo, idade, grau de inclusão dentária e presença de lesões associadas. A melhor forma de tratamento, dependendo do caso é a cirúrgica, que consiste em colocar os dispositivos de fixação intraóssea. O propósito deste trabalho é apresentar uma abordagem do facilitada e conservadora para o tratamento de fraturas de ângulo mandibular, além de desmistificar a contraindicação do acesso intra-oral para casos de fraturas desfavoráveis ao deslocamento. Este estudo, além disso, relata dois casos clínicos de fraturas de ângulo mandibular na presença de um terceiro molar impactado tratados por meio de acesso intrabucal definido pela técnica de Champy da linha oblíqua externa com o uso de placa única no consultório odontológico. Esta abordagem é adequada para casos com pouco deslocamento da linha de fratura e quando o paciente se mostra colaborador. Esta técnica permite rápida resolução, reduz os gastos com hospital e as sequelas pós-operatórias porque impede a necessidade de acesso extraoral.

Descritores: Fixação de Fratura; Terapêutica; Anestesia Local; Dente Serotino.

\section{Resumen}

La región del ángulo mandibular está consagrada en la literatura como una zona frágil debido a la presencia tercer molar aún más cuando su impación perfila como una complicación poco frecuente asociado con más intentos a la extracción del diente. Hay varios factores que influyen en la posibilidad de fractura como el género, la edad, el grado de inclusión dental y la presencia de lesiones asociadas. La mejor forma de tratamiento dependiendo del caso es quirúrgico, que consiste en la colocación de los dispositivos de fijación intraósea. Se muestra el propósito de facilitar tanto un enfoque conservador para el tratamiento de las fracturas del ángulo mandibular. Además, desmitificar la contraindicación del acceso intraoral para los casos de fracturas desfavorables al desplazamiento. Métodos: Este estudio, además, ha habido informes de dos casos clínicos de fracturas de ángulo mandibular en la presencia de un tercer molar incluido tratados mediante el acceso intraoral fijado por Champy técnica de la línea oblicua externa con el uso de una sola placa en el consultorio dental. Resultados: Este enfoque es muy adecuado para los casos con poco desplazamiento de la línea de fractura y cuando el paciente muestra coloborador. Conclusión: Esta técnica, así como rápido, reduce el gasto en el hospital, además de reducir las secuelas postoperatorias, ya que evita la necesidad de acceso extraoral.

Descriptores: Fijación de Fractura; Terapéutica; Anestesia Local; Tercer Molar. 


\section{INTRODUCTION}

In epidemiological terms mandibular fractures account for Wulkan et al. ${ }^{1}$ ranges from $20 \%$ to $50 \%$ from facial fractures have to Zix et al. ${ }^{2}$ is configured as 15.5 to $59 \%$ of mandibular fractures. This may due to its large projection in the face and in the presence of a mobile skull $^{3}$ the bone structure.

Among the affected regions, the most prevalent were the mandibular angle fractures (39\%), parasymphysis (19\%) and mandibular body (18\%) being simple fractures in $48 \%$ of cases and multiple in $52 \%$ of cases presented by Desai et al. ${ }^{4}$ either by physical attacks or the most frequent every day as automobile accidents, bicycle, monocycle ${ }^{5}$.

The treatment option is used most clearly open reduction and immobilization of mandibular fractures as soon as the patient has stable ${ }^{4}$ systemic conditions. Whereas important items as mentioned Ellis et al ${ }^{6}$ such as patient age, degree of displacement of fracture and the time elapsed injury ${ }^{6}$.

In the mandibular angle fractures the fragility of the third molar presence is demonstrated by good portion of literature ${ }^{7-10}$. Good part of the literature also calls for extra-oral access under general anesthesia for the surgical treatment of fractures with angular access submandibular $^{11,}$ particularly in situations of large displacements of the bone stumps fractured ${ }^{12}$.

In order to facilitate the treatment of mandibular angle invoices little displaced in collaborative patients with reduced muscle strength, as the females, favorable about the direction fracture, aims to here the description of two cases with treatment of such fractures by intraoral access performed in the dental office with a sign accompanying the external oblique line mandíbule ${ }^{13}$ this goal which underlines the great indication of intraoral access for cases of fractures favorable to displacement.

\section{CASE REPORT}

\section{-PATIENT 1}

Female patient, leucoderma, 19 years old, sought treatment in the emergency department and Emergency Municipal Santa Casa de Araçatuba, reporting being a victim of falling from a height and, with trauma to the lower face. In the initial assessment team of Surgery and Maxillofacial, upon request of the medical team, the patient showed a good general condition, ambulating, conscious, oriented, ruddy, hydrated, eupneic, afebrile, anicteric and cyanosis. Showing in discreet face facial asymmetry, the edema expense submandibular right.

The patient had mild dysesthesia in the lower lip and maintenance of dental occlusion. On imaginological examination fracture line in right mandible angle region with third molar included was observed (Figure 1). It was proposed surgery for reduction and fixation of fracture under local anesthesia in the office environment.

Local anesthesia was performed to desensitization of the branches of the inferior alveolar nerve, buccal and lingual fracture side with mepivacaine 2\% with vasoconstrictor - Epinephrine 1: 100,000. The incision in this region with blade 15 was made with the mucoperiosteal detachment for exposure of mandibular angle fracture.

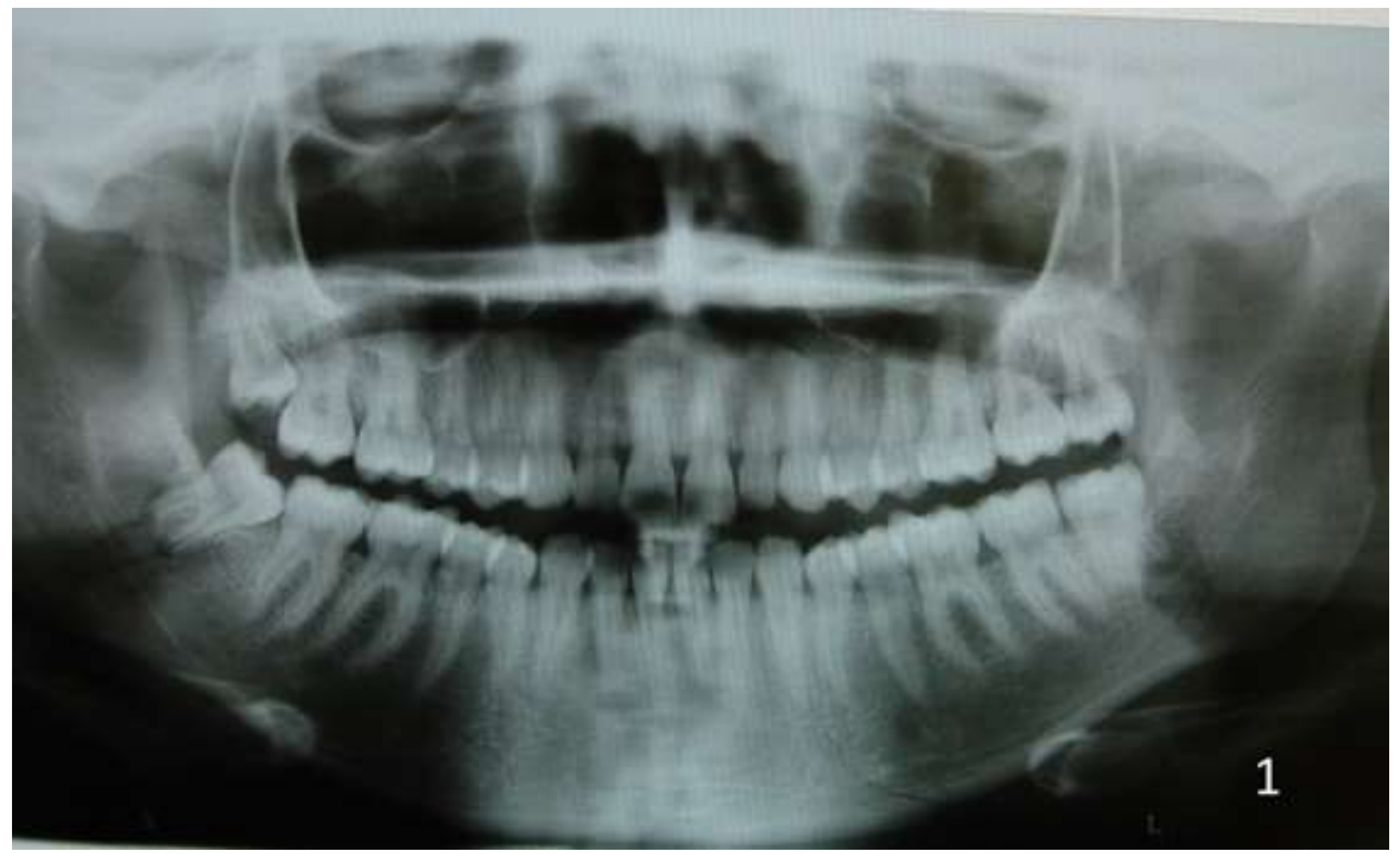

Figure 1. Ortopantomograph exam. Presence of fracture line in right mandible angle region with the presence of third molar 
In the case of patient with all upper and lower teeth, it was achieved not only an anatomic reduction and occlusion of same without the need for intermaxillary block. At this time, installed a titanium plate of $1.5 \mathrm{~mm}$ and 6 system monocortical titanium screws following the oblique line of the mandible followed by extraction of the corresponding dental element and copious irrigation with saline $0.9 \%$ and suture region vicryl 5-0 (Figures 2 a to $2 \mathrm{~d}$ ).

In addition, the patient proved quite aware of the need for post-operative care was instructed as to the restriction of diet on the consistency of food for at least 90 days. It was accompanied for a year in weekly outpatient surgery and Maxillofacial the State University of Sao Paulo of Araçatuba Dental School without any complications.
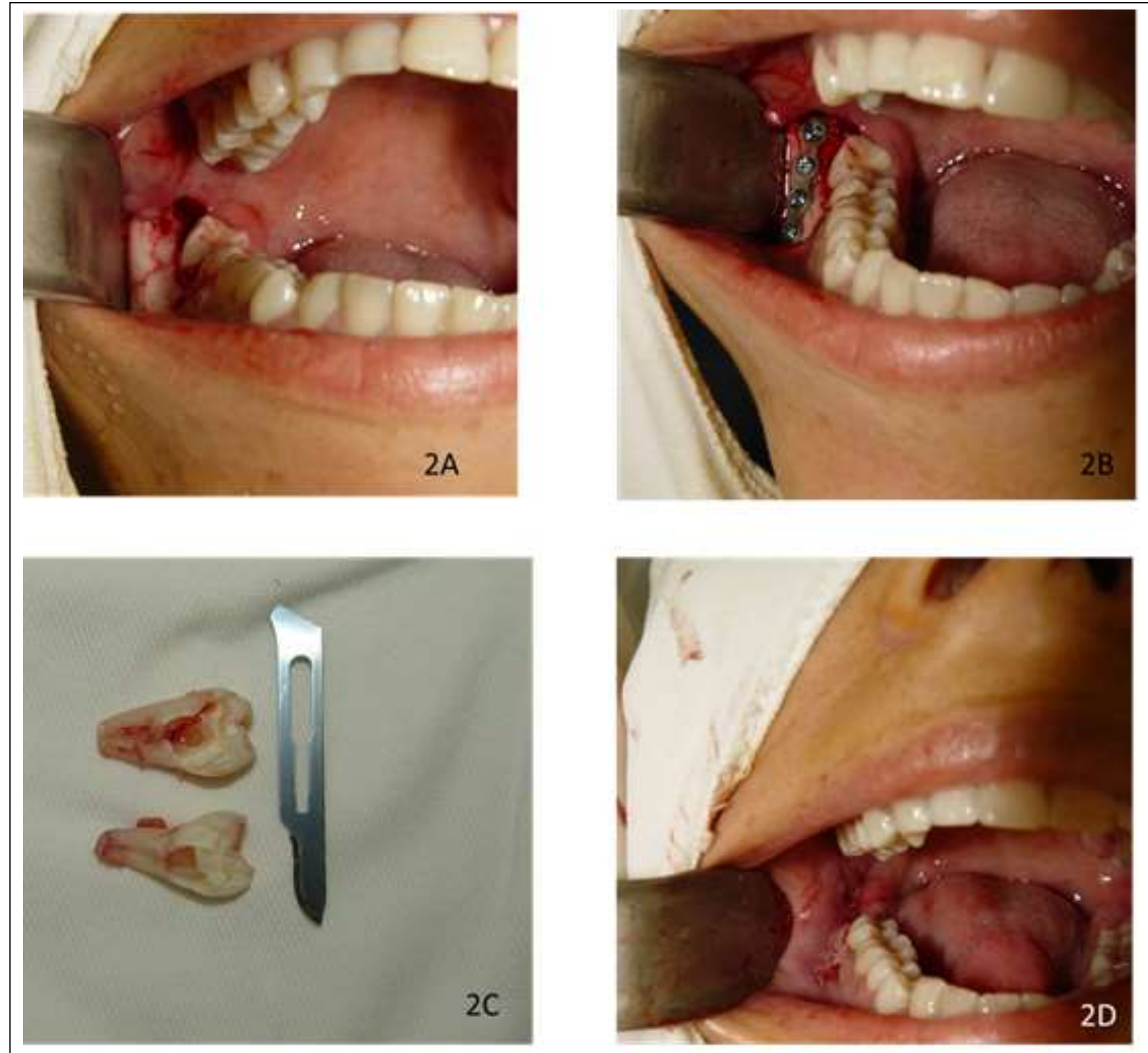

Figure 2. 2a. Oral access. 2b. Installed a titanium plate of $1.5 \mathrm{~mm}$ and 6 system monocortical titanium screws following the oblique line of the mandible. 2c. extraction of the corresponding dental. 2 d.suture region vicryl 5-0

\section{-PATIENT 2}

Female patient, leucoderma, 25 years old, sought treatment in the same way as above the Emergency Department and Emergency Santa Municipal House of Araçatuba, reporting being a victim of fall from height going to face against the object blunt (counter) and, with trauma in lower face. In the initial evaluation of the patient showed a good general condition, conscious, oriented, moisturized, and with the same general clinical characteristics of the previous patient and also with slight camber angle mandibular right and slight numbness in the lower lip without changing the dental occlusion.

On imaginological examination the same trace of fracture in right mandible angle region with the presence of the third molar was observed. It was therefore proposed for surgery for reduction and fixation of 
fracture under local anesthesia in the office environment

(Figure 3).

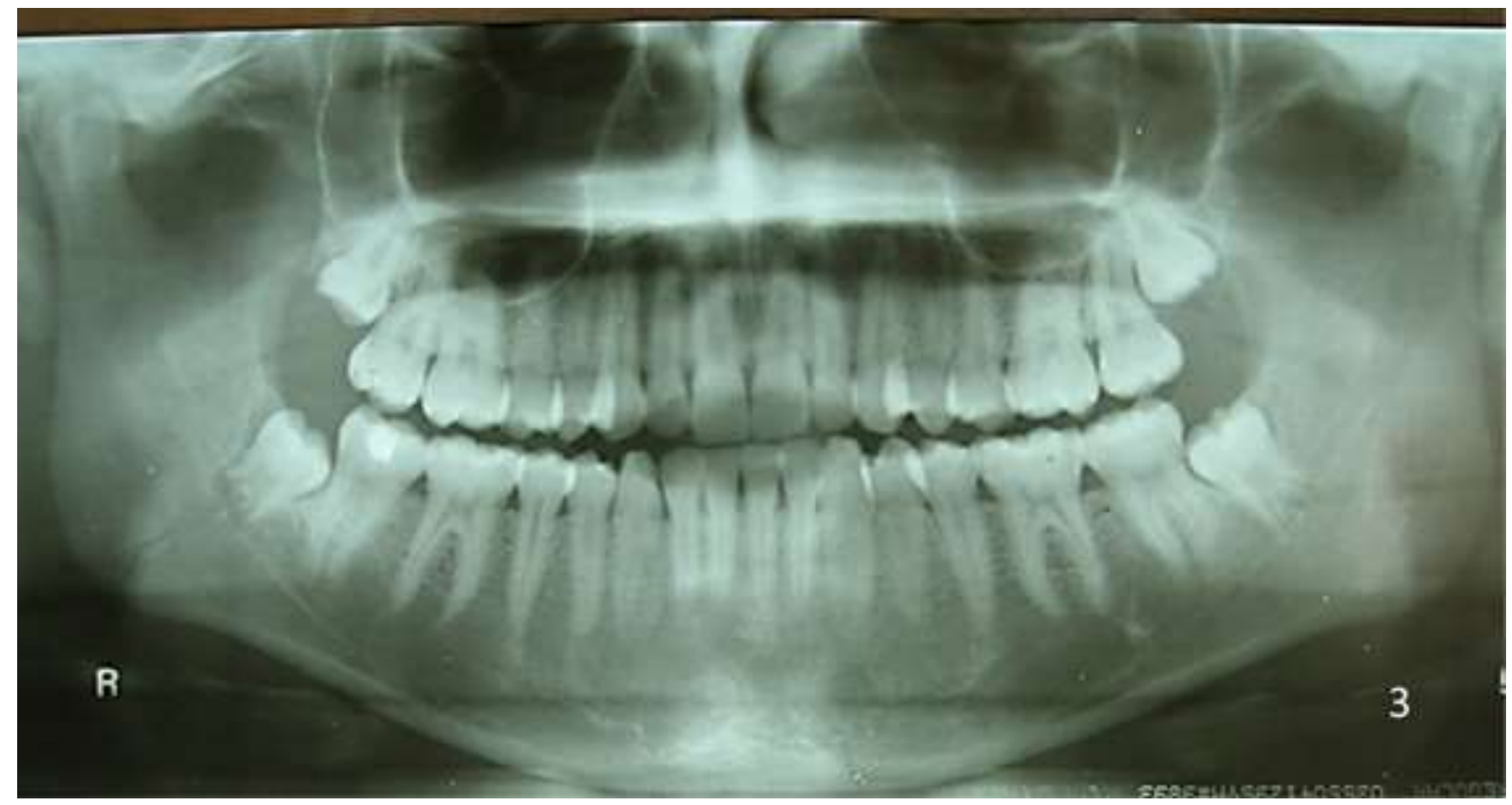

Figure 3. Ortopantomograph exam. Presence of fracture line in right mandible angle region with the presence of third molar included.

Local anesthesia was performed to desensitization of the branches of the inferior alveolar nerve, buccal and lingual fracture side with mepivacaine 2\% with vasoconstrictor - Epinephrine 1: 100,000. The incision in this region with blade 15 was made with the mucoperiosteal detachment for exposure of mandibular angle fracture.

As in the previous case, the patient until being young had all dental elements present which facilitated the anatomical and functional reduction of the same without the need for intermaxillary block. At this time, we installed a $1.5 \mathrm{~mm}$ titanium plate system and 6 monocortical titanium screws following the oblique line followed jaw abundant irrigation with saline $0.9 \%$ and suturing the region with Vicryl 5-0 (figures $4 a-4 c$ ).

The patient was also well aware of the need for post-operative care was instructed as to the diet restriction as to the consistency of the food for at least 90 days. It was accompanied for a year in weekly outpatient surgery and Maxillofacial the State University of Sao Paulo of Araçatuba Dental School without any complications.

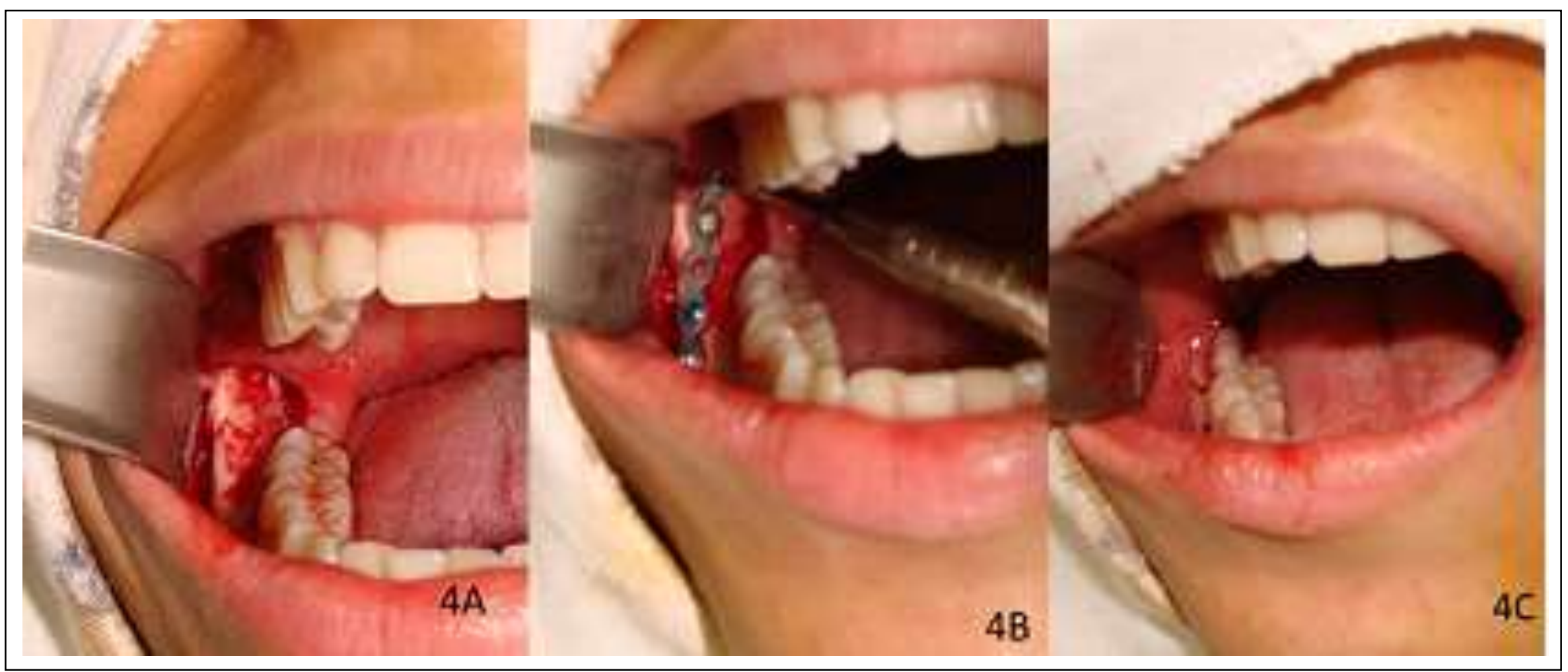

Figure 4. 4a. Oral access. 4b. Installed a titanium plate of $1.5 \mathrm{~mm}$ and 6 system monocortical titanium screws following the oblique line of the mandible. $4 \mathrm{c}$. Suture region vicryl 5-0 


\section{DISCUSSION}

For the surgical treatment of mandibular fractures there is the need to make incisions whether, facial or intraoral for exposure and reduction of fracture lines. In this sense many surgical approaches the jaw are proposed in the literature of which intraoral, submandibular, retromandibular, preauricular and access to rhytidectomy as mentioned by Ellis et al. ${ }^{12}$.

Normally used for the anterior region of the jaw symphysis and mandibular body - and in some angle fractures cases no or little displaced and rarely to branch and condylar not provide visualization satisfatory ${ }^{12}$ which was not observed in the cases discussed since access intraoral showed no obstacles or problems to the surgery as the patients did not have any limitations that may be associated with mouth opening of difficulty something that has not occurred at the time of surgery as the patients as well as conscious and oriented not had such preoperative difficulty, which we also see the advantage of local anesthesia for the surgical procedure in situations of little displaced fractures with fracture lines favorable to functional and anatomical reduction as well as the psychological aspect of the patient, who were able to the procedure.

Contrary to the literature, citing the prevalence of men with mandibular fractures, in this case two women were carriers, even if young adults 19 to 25 years old as shown by mostly researched articles because they are more involved in accidents at work or falls by carelessness, timelessness and the activities carried out by this population ${ }^{14}$.

Relevant situation here to be addressed is the prevalence of mandibular angle fracture fragile region by the presence of third spring included. This is because as shown ${ }^{15}$ corroborated by the clinical cases presented. Another relevant factor is the use of local anesthesia in the cases presented without the need for hospitalization to relieve the local health system hospitalization time of greater need for expensive medications, staff and own operating room, making the much faster procedure and with the same effectiveness as in the hospital.

The presence of impacted teeth near the fracture can cause a marked reduction in local bone density which produces an area of greatest producing mandibular brittleness, facilitating in this way the angle fracture ${ }^{15}$.

Here we present two cases with intraoral approach in the treatment of mandibular angle fractures, especially in unfavorable to dislocation ${ }^{12,13}$ as recommended by Champy $1976^{13}$ already indicated to the application of a plate and screws monocortical following the external oblique line of the mandible with long-term success after tooth extraction in the same surgical procedure and patient employees with postoperative dietary restriction of at least 90 days, simplifying the technique for treatment of mandibular angle fractures, through intraoral access, easier, faster, cheap, and safe ${ }^{16,17}$.

\section{CONCLUSION}

From what has been exposed intraoral access in selected patients gives a satisfactory result in long, uneventful intraoral approach in the treatment of mandibular angle fractures under local anesthetic shown very promising, faster and lower cost to the system health or even the patient avoiding the process of hospitalization and surgical center .

\section{REFERENCES}

1. Wulkan M, Parreira JR, Botter DA. Epidemiologia do trauma facial. Rev Assoc Med Bras. 2005; 51(5):290-5.

2. Zix JA, Schaller B, Lieger O, Saulicic N, Thoren H, Iizuka T. Incidence, aetiology and pattern of mandibular fractures in central Switzerland. Swiss Med Wkly. 2011 May 27;141:w13207. doi: 10.4414/smw.2011.13207.

3. Andrade Filho EF, Fadul Jr R, Azevedo RA, Rocha MAD, Santos RA, Toledo SR, et al. Fraturas de mandíbula: análise de 166 casos. Rev Assoc Med Bras. 2000; 46(3):272-6.

4. Desai J, Lownie JF, Cleaton-Jone P. Prospective audit of mandibular fractures at the Charlotte Maxeke Johannesburg Academic Hospital. S Afr j surg. 2010; 48(4):122-6.

5. Motamedi MH. An assesment of maxillofacial fractures: a 5-year study of 237 patients. J oral Maxillofac Surg. 2003 Jan;61(1):61-4.

6. Ellis $\mathrm{E} 3^{\text {rd }}$, Muniz O, Anand K. Treatment considerations for comminuted mandibular fractures. J oral Maxillofac Surg. 2003 Aug;61(8):861-70.

7. Halmos DR, Ellis E 3rd, Dodson TB. Mandibular third molars and angle fractures. J Oral Maxillofac Surg. 2004 Sep;62(9):1076-81.

8. Iida S, Hassfeld S, Reuther T, Nomura K, Muhling J. Relationship between the risk of mandibular angle fractures and the status of incompletely erupted mandibular third molar. J Craniomaxillofac Surg. 2005 Jun;33(3):158-63.

9. Zhu SJ, Choi BH, Kim HJ, Park WS, Huh JY, Jung $\mathrm{JH}$, et al. Relationship between the presence of unerupted mandibular third molars and fractures of the mandibular condyle. Int J Oral Maxillofac Surg. 2005 Jun;34(4):382-5.

10. Duan DH, Zhang Y. Does the presence of mandibular third molars increase the risk of angle fracture and simultaneously decrease the risk of condylar fracture? Int J Oral Maxillofac Surg. 2008 Jan;37(1):25-8.

11. Risdon F. Ankylosis of the temporo-mandibular joint 
J Am Den. Assoc 1934; 21:1933-7.

12. Ellis E III, Zide MF. Surgical approaches to the facial skeleton. Philadelphia: Lippincott Williams \& Wilkins; 2006.

13. Champy M, Lodde JP. [Mandibular synthesis. Placement of the synthesis as a function of mandibular stress]. Rev. Stomatol Chir Maxillofac. 1976 Dec;77(8):971-6.

14. Gaetti-Jardim EC, Faverani LP, Gulinelli JL, Queiroz TP, Mgro Filho, O, Garci Júnior IR. Epidemiologia das fraturas mandibulares em pacientes atendidos na região de Araçatuba. Rev. bras. Cir. Bucomaxilofac. 2010; 10(1):39-44.

15. Fernandes ESP, Silva KFO, Guimarães RMP, Vasconcelos BCE, Carneiro SCAS. Prevalence of Mandibular Condylar Fractures associated with the Presence or Absence of the Lower Third Molar On Orthopantomographic Imaging. Rev Cir Traumatol Buco-Maxilo-Fac. 2012; 12(1):61-8.

16. Digman RO, Natvig P. Cirurgia das Fraturas Faciais . São Paulo: Ed. Santos; 1983.

17. Colombini NEP. Cirurgia Maxilofacial. São Paulo: Ed. Pancast; 1991.

\section{CONFLICTS OF INTERESTS}

The authors declare no conflicts of interests.

\section{CORRESPONDING AUTHOR}

Ellen Cristina Gaetti-Jardim

ellengaetti@gmail.com

Received 05/07/2016 Accepted 09/08/2016 